\title{
Pengaruh Metode Pembelajaran dan Minat Baca Terhadap Hasil Belajar Sejarah Siswa SMAN 01 Argamakmur Bengkulu Utara
}

\author{
Yanuar Al-Fiqri ${ }^{1}$ \\ Kurniawati $^{2}$ \\ Sarkadi $^{3}$
}

\begin{abstract}
The purpose of this research is to determine whether the teaching method and reading interest affecting the historical learning outcome of the High School Student. The sample in this research is the student of SMAN 01 Argamakmur. This research used the quantitative research method with ANAVA $2 \times 2$. The result indicated: (1) Historical learning outcome of the student who applied the PQ4R method is higher than student who apllied the Direct instruction method. (2) There are interaction between teaching method and reading interest who affected the student hictorical learning outcome. (3) The historical learning outcome of the student who had a high interest in reading and applied the PQ4R method are higher than student who applied the direct instructional teaching method. (4) The historical learning outcome of the student who had a lowest interest in reading and applied the direct instructional teaching method are higher than student who applied the PQ4R method. In conclusion, teaching method and reading interest affecting the student historical learning outcome of the High School Student.
\end{abstract}

Keyword: PQ4R Teaching method, Reading Interest, Historical learning outcome.

\begin{abstract}
Abstrak: Penelitian ini bertujuan untuk mengetahui apakah terdapat pengaruh antara metode pembelajaran dan minat baca siswa terhadap hasil belajar sejarah siswa SMA. Sampel dalam penelitian ini adalah siswa SMAN 01 Argamakmur. Penelitian ini menggunakan metode eksperimen dengan desain faktorial 2x2. Hasil penelitian menunjukkan: (1) hasil belajar sejarah siswa yang diberikan metode pembelajaran $P Q 4 R$ lebih tinggi dari siswa yang diberikan metode pembelajaran langsung. (2) terdapat pengaruh interaksi antara metode pembelajaran dan minat baca siswa terhadap hasil belajar sejarah. (3) hasil belajar sejarah siswa yang memiliki minat baca tinggi dan diberikan metode pembelajaran $P Q 4 R$, lebih tinggi dari siswa yang diberikan metode pembelajaran langsung. (4) hasil belajar sejarah siswa yang memiliki minat baca yang rendah dan diberikan metode pembelajaran PQ4R lebih rendah dari siswa yang diberikan metode pembelajaran langsung. Kesimpulan dalam penelitian ini adalah, metode pembelajaran dan minat baca siswa mempengaruhi hasil belajar sejarah siswa SMA.
\end{abstract}

Kata kunci: Metode pembelajaran PQ4R, Minat Baca, hasil Belajar Sejarah

\section{PENDAHULUAN}

Belajar adalah suatu proses mencari dan mentransfer ilmu dan pengetahuan, dengan tujuan membuat manusia tahu dan mengerti lebih banyak akan lingkungan sekitarnya. Hasil dari pembelajaran inilah yang nantinya akan memudahkan hidup manusia ke depannya. Hasil dari proses pembelajaran tidak hanya terfokus kepada perubahan dari tidak tahu menjadi tahu, namun juga adanya perubahan di dalam sikap diri manusia yang menjadi lebih baik, serta berkembangnya kemampuan fisik dan keterampilan manusia. Tiga aspek yang menjadi standar hasil pembelajaran ini, yaitu pengetahuan, perubahan sikap, serta fisik dan keterampilan, lebih dikenal dengan kognitif, afektif dan psikomotorik.

\footnotetext{
${ }^{1}$ SMA Negeri 01 Argamakmur Bengkulu Utara, email: fissejarahunj@gmail.com, HP.087784395996

${ }^{2}$ Fakultas Ilmu Sosial Universitas Negeri Jakarta, email kurniawati204@ gmail.com HP.08129612145

${ }^{3}$ Fakultas Ilmu Sosial Universitas Negeri Jakarta, email sarkadi09@yahoo.co.id HP. 08179143181
} 
Inti dari pembelajaran di sekolah adalah bagaimana siswa dapat mengingat materi belajar yang telah diajarkan, memahaminya, serta mampu mengaplikasikan hasil belajar mereka tersebut ke dalam kehidupan sehari-hari mereka. Maka dari itu, mengingat akan materi ajar adalah hal yang paling esensial bagi siswa, sebelum dapat melanjutkan pembelajaran ke jenjang yang lebih tinggi. dalam dimensi tujuan pembelajaran kognitif milik Anderson (2015:43), ia menempatkan ranah "mengingat" sebagai dimensi kognitif paling awal yang harus dipenuhi. Hal ini menandakan bahwa "mengingat" materi pembelajaran menjadi persyaratan untuk dapat menguasai jenjang ranah kognitif selanjutnya yaitu memahami, mengaplikasikan, menganalisis ,mengevaluasi dan mencipta. Ke enam aspek kognitif ini saling terkait satu sama lain, siswa tak akan mampu untuk melaju ke jenjang aspek kognitif yang lebih tinggi jika belum mampu memenuhi syarat yaitu menguasai aspek kognitif di bawahnya. Untuk mampu memahami materi pelajaran, siswa sebelumnya harus mampu mengingat materi ajar terlebih dahulu, dan begitu pun seterusnya.

Pemerintah Indonesia telah menyatakan bahwa pembelajaran sejarah di sekolah, memiliki tujuan utama sebagai pembentuk karakter bangsa. Yang dapat diartikan bahwa pembelajaran sejarah lebih menekankan dimensi aspek afektif sebagai tujuan pembelajarannya. Dengan memaknai berbagai peristiwa-peristiwa yang terjadi dimasa lampau, siswa diharapkan mampu untuk menggali nilai-nilai positif yang dapat mereka tanamkan ke dalam diri mereka, dan mereka aplikasikan ke kehidupan mereka di masyarakat.
Tentunya agar siswa dapat menggali dan menemukan esensi nilai-nilai positif yang terdapat dalam peristiwa-peristiwa sejarah di masa lampau, siswa diharapkan telah menguasai materi-materi ajar yang disampaikan, dalam hal ini berarti mampu mengingat dan memahami bahan ajar sejarah yang telah diberikan. Karena jika para siswa ternyata dalam pembelajaran belum berhasil menguasai materi ajar, maka dapat dipastikan mustahil bagi mereka untuk dapat menggali dan menemukan nilai-nilai positif dari sebuah peristiwa sejarah, dan kemudian menanamkan serta mengaplikasikan nilai-nilai tersebut ke dalam diri mereka. Maka dari itu, akan sangat baik bila pembelajaran sejarah di sekolah menggunakan metode pembelajaran yang menuntun siswa untuk dapat mengingat dan memahami materi ajar sejarah secara lebih baik.

Hasil observasi awal yang telah dilakukan di SMA Negeri 1 Argamakmur Bengkulu Utara menunjukkan hasil sebagai berikut: Hasil belajar sejarah siswa yang cukup memprihatinkan, dari sampel hasil belajar kelas XI IPS menunjukkan hampir $50 \%$ siswa tidak mencapai nilai kriteria ketuntasan minimum. Wawancara dengan guru bidang studi juga menunjukkan bahwa minat siswa terhadap pelajaran sejarah rendah, dan dalam mengajar guru tidak menggunakan metodemetode yang menarik, hanya terpaku pada proses diskusi, ceramah dan tanya-jawab.

Melihat hasil observasi di atas, maka peneliti tertarik untuk melakukan penelitian dan mencoba untuk menerapkan metode pembelajaran PQ4R di SMA Negeri 01 Argamakmur, yang diharapkan mampu untuk mengatasi berbagai persoalan yang berkaitan dengan pembelajaran sejarah, terutama hasil belajar yang cukup rendah. 
Dikarenakan metode PQ4R lebih menekankan kepada proses membaca bermakna dan terstruktur, maka minat membaca pada diri siswa menjadi faktor yang perlu diperhatikan. Siswa dengan minat membaca yang tinggi di-asumsikan bila diterapkan metode ini, maka proses dan hasil belajar yang dicapai akan baik, begitu pula sebaliknya dengan siswa yang memiliki minat membaca yang rendah.

Belajar adalah perubahan dalam disposisi atau kapabilitas manusia yang bertahan dalam jangka waktu lama dan bukan hasil dari pertumbuhan (Gredler:2011;174). Menurut Rathus (2010:189), dalam perspektif psikologi behavioristik, belajar adalah perubahan dalam perilaku yang relatif permanen sebagai hasil dari latihan dan pengalaman, sedangkan aliran kognitif mendefinisikan belajar adalah proses dimana makhluk hidup membuat sebuah perubahan berdasarkan pengalaman berinteraksi dengan lingkungan sekitar. Kemudian Semiawan (2007:6) menyatakan bahwa yang disebut dengan belajar merupakan perubahan perilaku, sifat dan kemampuan yang relatif permanen, yang datang dari dalam dirinya, dan dapat ditinjau terutama dari pengaruh lingkungan atau dari faktor genetis yang berbeda satu dengan yang lainnya.

Menurut Makmun (2009:160), Hasil belajar dapat dimanifestasikan dalam tiga wujud, yaitu: (1) Pertambahan materi pengetahuan yang berupa fakta, informasi, prinsip atau hukum, kaidah prosedur, pola kerja atau teori sistem nilainilai dan sebagainya (2) Penguasaan pola-pola perilaku kognitif (pengamatan) proses berpikir, mengingat atau mengenal kembali, perilaku afektif (sikap-sikap apresiasi, pengahayatan dan sebagainya); perilaku psikomotorik (keterampilan-keterampilan

psikomotorik, termasuk yang bersifat ekspresif (3) Perubahan dalam sifat-sifat kepribadian baik yang tangible maupun yang intangible. Perubahan tingkah laku juga merupakan ciri belajar, yang dapat dilihat dari bertambahnya keterampilan yang dimiliki. Berupa penambahan rasa percaya diri, merasakan manfaat belajar suatu materi sehingga memiliki kecakapan yang dapat dikembangkan lebih luas lagi (Daryanto:2015:37).

Hasil belajar menurut Jihad dan Haris (2010:14), dapat berupa pencapaian bentuk perubahan perilaku yang cenderung menetap dari ranah kognitif, afektif, dan psikomotor dari proses belajar yang dilakukan dalam waktu tertentu. Sehingga dapat dipahami bahwa melalui proses belajar perubahan tingkah laku yang dimaksud adalah perubahan dalam ketiga kawasan atau ranah tersebut.

Pembelajaran sejarah menurut Susanto (2014:41)), artinya mempelajari peristiwa yang dilakukan manusia pada masa lampau (the past human event) terjadi hanya sekali (einmalig) dan tidak terulang kembali. Karena itu mempelajari sejarah menjadi penting agar dapat menentukan tindakan yang tepat guna dalam melanjutkan masa depan yang sesuai dengan harapan masa lampau. Maka dari itu pembelajaran sejarah di sekolah sangat penting dilaksanakan secara baik dan benar, demi menciptakan generasi bangsa yang berkarakter.

Kochhar (2008:27) mengemukakan bahwa, sejarah diajarkan dalam rangka mencapai sasaran untuk meningkatkan pemahaman tentang diri sendiri; memberikan gambaran yang tepat tentang konsep waktu, ruang, dan masyarakat; membuat peserta didik untuk mampu 
mengevaluasi nilai-nilai dan hasil yang telah dicapai oleh generasinya; mengajarkan toleransi dan menanamkan sikap intelektualitas; mengajarkan prinsi-prinsip moral; menanamkan orientasi ke masa depan; memberikan pelatihan mental; memberikan pelatihan dalam menangani isu-isu kontroversial; membantu mencarikan jalan keluar bagi berbagai masalah sosial dan perseorangan; memperkokoh rasa Nasionalisme; mengembangkan pemahaman internasional; dan mengembangkan keterampilan-keterampilan yang berguna.

Selain itu, Hasan (2012:87) juga menyatakan bahwa tujuan pendidikan sejarah di SMA adalah: (1) Mengembangkan kemampuan berpikir kronologis, kritis dan kreatif; (2) Membangun kepedulian sosial; (3) Mengembangkan semangat kebangsaan; (4) Membangun kejujuran, kerja keras, dan tanggung jawab; (5) Mengembangkan rasa ingin tahu; (6) Mengembangkan nilai dan sikap kepahlawanan serta kepemimpinan; (7) mengembangkan kemampuan berkomunikasi; (8) mengembangkan kemampuan mencari, mengolah, mengemas, dan mengkomunikasikan informasi.

Berdasarkan beberapa penjelasan di atas, maka dapat disimpulkan bahwa hasil belajar sejarah adalah perubahan yang muncul pada diri siswa setelah mengikuti pembelajaran sejarah, perubahan ini mencakup aspek kognitif (pengetahuan), afektif (sikap) dan psikomotorik (keterampilan) pada diri siswa, perubahan pada ketiga aspek tersebut bersifat permanen dan dapat diamati dan diukur melalui tes hasil belajar. Berdasarkan definisi diatas, maka fokus hasil belajar sejarah dalam penelitian ini adalah hasil belajar sejarah dimensi kognitif (pengetahuan) yang diukur dengan menggunakan tes hasil belajar setelah siswa menjalani pembelajaran sejarah dikelas.

Trianto (2014:178) menjelaskan Metode PQ4R adalah salah satu metode yang digunakan untuk membaca buku pelajaran dan bahan bacaan lainnya dalam suatu bidang pengetahuan. Metode ini merupakan salah satu bagian dari strategi elaborasi. Strategi ini digunakan untuk membantu siswa mengingat apa yang mereka baca, dan dapat membantu proses belajar mengajar dikelas yang dilaksanakan dengan kegiatan membaca buku.

Chipman dkk (2009:55) menjelaskan tentang metode PQ4R sebagai berikut: That technique for improving retention of normal texts involves the reader Previewing of suveying the chapter, the making up question about each section, then reading each section, trying to answer the question, and reflecting on the texts in the process, reciting the information in a section when finished, and finnaly reviewing the chapter, recalling its main points when chapter is finished. Berdasarkan penjelasan di atas, kita dapat menjelaskan tentang apa itu metode PQ4R. Metode yang merupakan singkatan dari proses Preview, Question, Reading, Reflect, Recite dan Review. Preview adalah proses dimana pembaca mensurvey atau membaca secara singkat bahan bacaan, setelah itu menyusun pertanyaan (Question) tentang bahan bacaan, kemudian mencoba untuk menjawab pertanyaan tersebut dengan membaca (Read) bahan bacaan secara menyeluruh, saat membaca pembaca juga melakukan proses reflect dan menulis ulang (Recite) informasi yang penting yang didapat saat membaca dan terakhir adalah proses megkaji ulang bahan bacaan (Review) 
Menurut Slavin (2008:256) riset telah memperlihatkan keefektifan metode PQ4R untuk siswa yang lebih dewasa dan alasannya adalah dengan mengikuti prosedur PQ4R, siswa terfokus pada pengorganisasian informasi yang bermakna dan melibatkan mereka dalam strategi yang efektif lainnya, seperti perumusan pertanyaan, penjabaran dan praktik pendistribusian atau kesempatan mengkaji kembali informasi dalam suatu kurun waktu.

Metode PQ4R memiliki karakteristik sebagai berikut: mengacu pada perilaku dan proses berpikir, termasuk proses memori dan metakognitif, yang secara langsung terlibat dalam menyelesaikan tugas belajar. Mengajarkan siswa untuk belajar atas kemauan sendiri, sehingga membentuk siswa sebagai pembelajar mandiri melalui kegiatan mendiagnosa suatu pembelajaran tertentu, memilih strategi belajar untuk menyelesaikan belajar yang dihadapi, memonitor keefektifan strategi yang digunakan sehingga siswa termotivasi untuk terlibat dalam situasi belajar sampai masalah terselesaikan (Uno:2011:133).

Langkah-langkah yang harus dilakukan dalam metode PQ4R adalah sebagai berikut: Preview: Langkah pertama ini dimaksud agar siswa membaca selintas dengan cepat sebelum memulai membaca bahan bacaan siswa yang memuat tentang materi ekosistem peran dan interaksinya. Siswa dapat memulai dengan membaca topik, subtopik utama, judul dan sub judul, kalimat-kalimat permulaan atau akhir suatu paragraf, atau ringkasan akhir suatu bab. Apabila hal itu tidak ada, siswa dapat memeriksa setiap halaman dengan cepat, membaca satu atau dua kalimat disana-sini sehingga diperoleh sedikit gambaran mengenai apa yang akan dipelajari. Perhatikan ide pokok yang akan menjadi inti pembahasan dalam bahan bacaan siswa. Dengan ide pokok ini akan memudahkan mereka memberi keseluruhan ide yang ada.

Question: Langkah kedua yaitu mengajukan pertanyaan kepada diri sendiri untuk setiap pasal yang ada pada bahan bacaan siswa. Pergunakan judul, sub judul atau topik dan sub topik utama. Awali pertanyaan dengan menggunakan kata; apa, siapa, mengapa dan bagaimana.

Read: Baca karangan itu secara aktif, yakni dengan cara pikiran siswa harus memberikan reaksi terhadap apa yang dibacanya. Dan mencoba mencari jawaban terhadap semua pertanyaan yang diajukan sebelumnya.

Reflect: bukanlah suatu langkah terpisah dengan langkah ketiga (read) melainkan merupakan suatu komponen esensial dari langkah ketiga tersebut. Selama membaca, siswa tidak hanya cukup mengingat atau menghafal, tetapi cobalah untuk memahami informasi yang dipresentasikan dengan cara: (1) menghubungkan informasi itu dengan hal-hal yang telah anda ketahui; (2) mengaitkan subtopik didalam teks dengan konsep atau prinsip-prinsip utama; (3) cobalah untuk memecahkan kontradiksi didalam informasi yang disajikan; dan (4) cobalah untuk menggunakan materi itu untuk memecahkan masalah yang disimulasikan dan dianjurkan dari materi pelajaran tersebut.

Recite: Pada langkah kelima ini siswa diminta untuk merenungkan (mengingat) kembali informasi yang telah dipelajari dengan menyatakan butir-butir penting dengan nyaring dan dengan menanyakan dan menjawab 
pertanyaan. Siswa dapat melihat kembali catatan yang telah dibuat dan menggunakan kata-kata yang ditonjolkan dalam bacaan. Dari catatan yang telah dibuat pada langkah terdahulu dan berlandaskan ide-ide yang ada pada siswa, maka mereka diminta membuat inti sari materi dari bacaan.

Review: Pada langkah terakhir ini siswa diminta untuk membaca catatan singkat (intisari) yang telah dibuatnya, mengulang kembali seluruh isi bacaan bila perlu dan sekali lagi jawab pertanyaan yang diajukan (Trianto:2014:179-181).

Metode pembelajaran langsung merupakan pembelajaran yang terfokus pada guru mengetahui pengetahuan baru yang akan didapatkan oleh siswa. Suyono dan Hariyanto (2015:86) menjelaskan bahwa pembelajaran langsung didefinisikan sebagai model pembelajaran yang berorientasi pada tujuan dan distrukturkan oleh guru, dan dengan landasan itu guru mentransformasikan pengetahuan atau keterampilan secara langsung kepada siswa. Peran guru yang dominan menjadikan guru sebagai satusatunya sumber informasi yang didapatkan siswa. Pembelajaran dilaksanakan dengan lebih banyak pada penyampaian informasi secara sepihak oleh guru. Lebih lanjut, Suprijono (2016:185) menjelaskan bahwa Pembelajaran langsung merupakan suatu model pembelajaran terbimbing, karena guru dalam proses pembelajaran menerapkan praktik terkontrol dan praktik terbimbing. Dimulai dengan penyajian konsep atau keterampilan baru, yang menekankan pada kualitas penjelasan guru.

Metode pembelajaran langsung ini sering dimasukkan ke dalam kelompok model pembelajaran yang konvensional. Sama halnya dengan berbagai metode dan model pembelajaran lainnya, metode pembelajaran langsung tentu memiliki beberapa kelebihan dan kekurangan. Kelebihan dari pembelajaran langsung yakni: 1) merupakan pembelajaran yang dirancang untuk pengetahuan faktual dan prosedural, 2) sangat sesuai diimplementasikan pada pengetahuan tentang aturan, prosedur, dan keterampilan dasar. Adapun kekurangan dari pembelajaran langsung yakni: 1) membutuhkan lingkungan belajar yang sangat terstruktur dan orkestrasi yang cermat oleh guru, 2) menempatkan siswa sebagai pengamat, pendengar dan partisipan yang tekun, 3) membutuhkan keterampilan manajemen kelas yang unik untuk mempertahankan perhatian siswa dalam jangka waktu yang cukup lama (Suprijono:2016:181-182).

Menurut Basri (2015:54) Minat atau Interest adalah kecenderungan dan gairah yang tinggi terhadap sesuatu. Sedangkan menurut Slameto (2010:180), minat adalah suatu rasa lebih suka dan rasa keterikatan pada suatu hal atau aktivitas, tanpa ada yang menyuruh. Minat pada dasarnya adalah penerimaan akan suatu hubungan antara diri sendiri dengan sesuatu di luar diri. Semakin kuat atau dekat hubungan tersebut, semakin besar minat. Minat pada diri siswa sangat bergantung pada pandangan siswa terhadap suatu kegiatan dan mata pelajaran tertentu, semakin merasa penting menguasai suatu kegiatan dan mata pelajaran, maka minat yang terbentuk akan semakin tinggi pula, sebaliknya jika siswa tidak merasa memiliki kebutuhan dan kepentingan terhadap kegiatan dan pelajaran tertentu, maka akan semakin rendah pula minat mereka.

Menurut Sadirman (2007:76), minat dapat diartikan sebagai suatu kondisi yang terjadi 
apabila seseorang melihat ciri-ciri atau arti sementara situasi yang dihubungkan dengan keinginan-keinginan atau kebutuhankebutuhannya sendiri. Renninger dan Hidi (2016:8). menyatakan bahwa minat juga bisa didefinisikan sebagai Kondisi psikologis seseorang saat melakukan suatu aktivitas tertentu, dan juga kecenderungan kognitif dan afektif seseorang yang memotivasinya untuk kembali melakukan suatu aktivitas tertentu tersebut.

Slameto (2010:180) menyatakan bahwa, mengembangkan minat terhadap sesuatu pada dasarnya adalah membantu siswa melihat bagaimana hubungan antara materi yang diharapkan untuk dipelajarinya dengan dirinya sendiri sebagai individu. Proses ini menunjukkan pada siswa bagaimana pengetahuan atau kecakapan tertentu mempengaruhi dirinya, melayani tujuan-tujuannya, memuaskan kebutuhan-kebutuhannya. Bila siswa menyadari bahwa belajar merupakan suatu alat untuk mencapai beberapa tujuan yang dianggapnya penting, dan bila siswa melihat bahwa hasil dari pengalaman belajarnya akan membawa kemajuan pada dirinya. Kemungkinan besar ia akan berminat untuk mempelajarinya.

Hal tersebut menandakan bahwa, minat pada diri siswa sangat bergantung pada pandangan siswa terhadap suatu kegiatan dan mata pelajaran tertentu, semakin merasa penting menguasai suatu kegiatan dan mata pelajaran, maka minat yang terbentuk akan semakin tinggi pula, sebaliknya jika siswa tidak merasa memiliki kebutuhan dan kepentingan terhadap kegiatan dan pelajaran tertentu, maka akan semakin rendah pula minat mereka.
Dari beberapa penjelasan di atas, bisa disimpulkan bahwa minat pada diri siswa akan tumbuh jika ia memiliki kemauan dan keinginan yang tinggi terhadap suatu kegiatan tertentu, kemauan yang tinggi ini bisa didasari pada kesadaran siswa akan pentingnya suatu kegiatan tersebut demi mencapai tujuan dan hasil yang diinginkan oleh siswa. Jika dihubungkan dengan kegiatan membaca, maka bisa didefinisikan bahwa minat membaca adalah suatu kemauan dan keinginan yang tinggi yang ada pada diri siswa untuk melaksanakan kegiatan membaca, Kemauan dan keinginan yang tinggi untuk membaca ini didorong oleh kesadaran siswa akan pentingnya kegiatan membaca tersebut demi mencapai tujuan dan hasil yang diinginkan oleh siswa. Siswa yang memiliki minat baca yang tinggi, mampu untuk mengatasi berbagai permasalahan dan hambatan-hambatan yang mereka temukan sebelum kegiatan membaca, selama kegiatan membaca dan setelah kegiatan membaca dilaksanakan.

Studi yang dilakukan oleh Kirby (2011:276), menyatakan bahwa minat baca sangat berhubungan dengan kemampuan membaca. Hubungan antara minat dan kemampuan membaca ini walaupun lemah, mengindikasikan bahwa anak-anak yang memiliki minat yang rendah dalam membaca cenderung juga memiliki kemampuan membaca yang lemah. Maka dari itu, sangat penting bagi guru untuk mendorong siswa untuk memiliki minat dan kebiasaan membaca sedini mungkin. Sebagaimana yang dinyatakan oleh Palani (2012; 94), jika guru mampu menanam dan menumbuhkan ke dalam pikiran siswa tentang pentingnya membaca, maka akan memungkinkan siswa untuk terus membaca 
sepanjang hayat mereka dengan penuh keyakinan. Penggunaan bahan bacaan ringan seperti majalah dan koran, lama kelamaan ternyata mampu menjadi batu loncatan bagi para siswa untuk nantinya lebih berminat dalam membaca bahan bacaan yang lebih berat, terutama buku (Ortlieb, 2010:4).

Berdasarkan beberapa penjelasan diatas, dapat disimpulkan bahwa minat baca adalah suatu kemauan dan keinginan yang tinggi yang ada pada diri siswa untuk melaksanakan kegiatan membaca, Kemauan dan keinginan yang tinggi untuk membaca ini didorong oleh kesadaran siswa akan pentingnya kegiatan membaca tersebut demi mencapai tujuan dan hasil yang diinginkan oleh siswa.

Penelitian yang relevan dengan penelitian ini adalah penelitian yang dilakukan oleh Ruqiah Bibi dan Manzoor H. Arif (2011:247-267), yang berjudul: Effect of $P Q 4 R$ study strategy in scholastic achievement of Secondary School Student in Punjab (Pakistan). mengenai pengaruh strategi belajar PQ4R terhadap hasil belajar siswa Sekolah menengah di Pakistan. Hasil penelitian menunjukkan bahwa hasil belajar siswa kelas eksperimen, yang diterapkan metode PQ4R lebih tinggi dari siswa kelas kontrol.

Penelitian ini bertujuan untuk mengungkap pengaruh metode pembelajaran dan minat baca terhadap hasil belajar sejarah, maka penelitian ini memiliki tujuan untuk mengetahui: (1) Perbedaan hasil belajar sejarah antara siswa yang diterapkan metode pembelajaran PQ4R dengan siswa yang menggunakan metode pembelajaran langsung. (2) Pengaruh interaksi antara metode pembelajaran dan minat baca siswa terhadap hasil belajar sejarah. (3) Perbedaan hasil belajar sejarah antara siswa yang memiliki minat baca tinggi dan menggunakan metode pembelajaran PQ4R dengan siswa yang menggunakan metode pembelajaran langsung. (4) Perbedaan hasil belajar sejarah antara siswa yang memiliki minat baca rendah dan menggunakan metode PQ4R dengan siswa yang menggunakan metode pembelajaran langsung.

\section{METODE PENELITIAN}

Metode yang digunakan dalam penelitian ini adalah eksperimen dengan Desain Treatmen by level $2 \times 2$. Variabel dalam penelitian ini terdiri dari dua variabel bebas yaitu metode pembelajaran $\mathrm{PQ} 4 \mathrm{R}$ dan metode pembelajaran langsung. Sedangkan variabel terikatnya adalah hasil belajar sejarah siswa. Penelitian ini merupakan penelitian eksperimen menggunakan satu kelas kontrol dengan metode pembelajaran langsung dan satu kelas eksperimen dengan metode pembelajaran PQ4R.

Populasi dalam penelitian ini adalah siswa kelas XI IPS SMA Negeri 1 Argamakmur. Sedangkan sampel dalam penelitian dilakukan dengan teknik random sampling menggunakan undian dan diperoleh satu kelas kontrol yaitu XI IPS 1 dan satu kelas eksperimen yaitu XI IPS 3. Jumlah siswa yang menjadi subjek penelitian adalah 61 orang siswa dibagi menjadi dua kelompok masing-masing terdiri dari 30 siswa untuk kelas XI IPS 1 dan 31 siswa untuk kelas XI IPS 3. Sebelum diberikan perlakuan, dilakukan pembagian kuesioner untuk mengetahui tingkat minat baca siswa. Skor pengisian kuesioner tersebut tersusun berdasarkan skor tertinggi ke skor terendah. Setiap kelas ditetapkan 27\% dari rangking teratas digolongkan sebagai kelompok 
siswa yang memiliki minat baca tinggi dan $27 \%$ dari rangking terbawah digolongkan sebagai siswa dengan minat baca rendah.

Data yang dikumpulkan dalam penelitian ini meliputi data hasil belajar sejarah dan Minat baca siswa. Data hasil belajar Sejarah diambil dengan menggunakan instrumen penelitian berbentuk soal pilihan ganda (multiple choice). Sebelum di gunakan, Instrumen di uji terlebih dahulu validitasnya dengan menggunakan rumus point biserial correlation dan Reliabilitasnya menggunakan Rumus KR20. Untuk mengukur minat baca siswa, digunakan instrumen yang berbentuk angket, dan sebelum digunakan instrumen diuji validitasnya menggunakan rumus korelasi product moment dan Reliabilitasnya denga rumus alpha cronbach.

Data yang diperoleh melalui instrumen penelitian dianalisis menggunakan analisis deskriptif dan inferensial. Analisis deskriptif dilakukan dengan penyajian tabel distribusi, histogram, rata-rata dan simpangan baku. Uji normalitas dalam penelitian ini menggunakan Uji Liliefors. Sedangkan uji homogenitas menggunakan Uji Bartlett pada taraf pada taraf nyata signifikansi $\alpha=0,05$. Uji hipotesis dalam penelitian ini menggunakan uji analisis variansi (ANAVA) untuk menguji efek utama dan pengaruh interaksi antar A dan B. Pengujian dilanjutkan dengan menggunakan Uji Tuckey untuk melihat hasil perbandingan di antara kelompok perlakuan penelitian.

\section{HASIL DAN PEMBAHASAN}

Pengujian hipotesis dilakukan setelah data penelitian lolos uji persyaratan analisis, yaitu uji Normalitas dan Homogenitas. Uji normalitas dilakukan terhadap nilai hasil belajar sejarah siswa dari masing-masing kelompok yang terdiri dari enam kelompok data yang diuji normalitas distribusinya, yaitu: 1.Data hasil belajar sejarah secara keseluruhan kelompok siswa yang diberikan metode PQ4R (A1) 2. Data hasil belajar sejarah secara keseluruhan kelompok siswa yang diberikan metode pembelajaran langsung (A2) 3 . Data hasil belajar sejarah siswa yang diberikan metode PQ4R dan memiliki minat baca tinggi (A1B1) 4. Data hasil belajar sejarah siswa yang diberikan metode PQ4R dan memiliki minat baca rendah (A1B2) 5. Data hasil belajar sejarah siswa yang diberikan metode pembelajaran langsung dan memiliki minat baca tinggi (A2B1) 6. Data hasil belajar sejarah siswa yang diberikan metode pembelajaran langsung dan memiliki minat baca rendah (A2B2)

Pengujian normalitas data dilakukan dengan menggunakan uji Liliefors pada tarah signifikansi $\alpha=0,05$ dengan kriteria pengujian: apabila $\mathrm{L}_{\text {hitung }}(\mathrm{L} 0)$ lebih kecil dari $\mathrm{L}_{\text {tabel }}\left(\mathrm{L}_{\mathrm{T}}\right)$, maka data berdistribusi normal. Hasil perhitungan uji normalitas dapat dilihat pada tabel di bawah ini:

Tabel. 1 Rangkuman hasil Uji Normalitas (Liliefors) Data Hasil Belajar Sejarah

\begin{tabular}{|c|c|c|c|c|c|}
\hline Kel. & $\alpha$ & $\mathrm{N}$ & Lhitung & $\mathrm{L}_{\text {tabel }}$ & Ket \\
\hline A1 & \multirow{6}{*}{0,05} & 16 & 0,082 & 0,222 & Normal \\
\hline A2 & & 16 & 0,090 & 0,222 & Normal \\
\hline A1B1 & & 8 & 0,130 & 0,313 & Normal \\
\hline A1B2 & & 8 & 0,122 & 0,313 & Normal \\
\hline A2B1 & & 8 & 0,156 & 0,313 & Normal \\
\hline $\mathrm{A} 2 \mathrm{~B} 2$ & & 8 & 0,112 & 0,313 & Normal \\
\hline
\end{tabular}

Data pada tabel menunjukkan bahwa semua kelompok hasil belajar sejarah yang diuji menggunakan uji Liliefors memberikan nilai hasil perhitungan $\mathrm{L}_{\text {hitung }}$ lebih kecil dari $\mathrm{L}_{\text {tabel. }}$ Persyaratan normalitas terpenuhi karena seluruh hasil belajar sejarah dalam penelitian ini berasal dari populasi yang berdistribusi normal. 
Uji homogenitas dilakukan terhadap data kelompok perlakuan antara metode pembelajaran dan minat baca siswa ( A1B1, A1B2, A2B1, dan A2B2). Uji homogenitas data dilakukan dengan menggunakan uji Bartlett pada taraf signifikansi $\alpha$ $=0,05 ;$ dimana $\mathrm{dk}(1-\mathrm{a})(\mathrm{k}-1)$ dengan kriteria apabila nilai $X^{2}{ }_{\text {hitung }}$ lebih kecil dari nilai $X_{\text {tabel }}^{2}$ maka varians semua kelompok perlakuan bersifat homogen. Rangkuman hasil perhitungan pengujian homogenitas varians dapat dilihat pada tabel di bawah ini.

\section{Tabel. 2 Rangkuman Hasil Pengujian Homogenitas Varians Kelompok Kombinasi Perlakuan}

\begin{tabular}{|c|c|c|c|c|c|c|}
\hline Sampel & $\mathrm{db}$ & \begin{tabular}{|l|} 
Varians \\
Gabungan \\
\end{tabular} & B & $x^{2}{ }_{\text {hit }}$ & $x^{2}{ }_{\text {tab }}$ & Ket. \\
\hline A1B1 & 7 & \multirow{4}{*}{$\begin{array}{c}7,0267 \\
9\end{array}$} & \multirow{4}{*}{23,709} & \multirow{4}{*}{1,086} & \multirow{4}{*}{7,81} & \multirow{4}{*}{$\begin{array}{l}\text { Homo } \\
\text { gen }\end{array}$} \\
\hline A1B2 & 7 & & & & & \\
\hline A2B1 & 7 & & & & & \\
\hline $\mathrm{A} 2 \mathrm{~B} 2$ & 7 & & & & & \\
\hline
\end{tabular}

Data pada tabel menunjukkan bahwa $x^{2}$ hitung adalah 1,086 dan $x^{2}$ tabel adalah 7,81. Hasil uji homogenitas varians menyimpulkan bahwa $\mathrm{H}_{0}$ diterima, dan keempat kelompok perlakukan bersifat homogen sehingga persyaratan homogenitas terpenuhi.

Analisis data dilanjutkan dengan uji ANAVA untuk menguji hipotesis penelitian. Pengujian Hipotesis dilakukan untuk menguji efek utama dan efek interaksi dari metode pembelajaran terhadap hasil belajar sejarah. Dengan menggunakan analisis varians dua jalur ANAVA 2 X 2. Efek utama dalam penelitian ini adalah mengenai pengaruh penggunaan metode pembelajaran $\mathrm{PQ} 4 \mathrm{R}$ dan pembelajaran langsung dan minat baca terhadap hasil belajar sejarah siswa SMA Negeri 01 Argamakmur, sedangkan efek interaksi dalam penelitian ini adalah tentang adanya pengaruh interaksi antara siswa yang diberikan metode pembelajaran dengan minat baca yang tinggi dan rendah. Taraf signifikasinya dilakukan dengan uji lanjut menggunakan uji Tuckey

\section{Tabel .3 Rangkuman Hasil Perhitungan} Analisis dua jalur (ANAVA 2 x 2)

\begin{tabular}{|c|c|c|c|c|c|c|}
\hline \multirow{2}{*}{$\begin{array}{c}\text { Sumber } \\
\text { Variansi }\end{array}$} & Db & JK & RJK & F Fitung & \multicolumn{2}{|c|}{$F_{\text {tabel }}$} \\
\cline { 5 - 7 } & & & & & 0,05 & 0,01 \\
\hline $\begin{array}{c}\text { Antar } \\
\text { Kolom }\end{array}$ & 1 & 40,50 & 40,50 & $5,764 *$ & 4,20 & 7,64 \\
\hline Antar Baris & 1 & 6,13 & 6,13 & 0,872 & 4,20 & 7,64 \\
\hline Interaksi & 1 & 312,50 & 312,50 & $44,473 * *$ & 4,20 & 7,64 \\
\hline Dalam & 28 & 196,75 & 7,03 & & & \\
\hline $\begin{array}{c}\text { Total } \\
\text { Direduksi }\end{array}$ & 31 & 555,88 & & & & \\
\hline
\end{tabular}

Hipotesis pertama, yang dinyatakan dengan $\mathrm{H}_{0}: \mu \mathrm{A} 1 \leq \mu \mathrm{A} 2$ dan $\mathrm{H}_{1}: \mu \mathrm{A} 1>\mu \mathrm{A} 2$. Berdasarkan hasil perhitungan ANAVA dua jalur diperoleh data Fhitung untuk metode pembelajaran yaitu 5,764 sedangkan Ftabel pada taraf nyata signifikansi $\alpha=0,05$ adalah 4,20. Karena $\mathrm{F}_{\text {hitung }}>\mathrm{F}_{\text {tabel }}$ maha $\mathrm{H}_{0}$ ditolak dan $\mathrm{H}_{1}$ diterima. Dengan demikian dapat disimpulkan bahwa dalam penelitian ini terdapat perbedaan hasil belajar sejarah antara siswa yang diberikan metode pembelajaran PQ4R dengan siswa yang diberikan Metode pembelajaran langsung. Dikarenakan, Metode pembelajaran PQ4R adalah metode yang menuntun siswa untuk aktif dalam menguasai materi pelajaran dengan cara membaca secara terstruktur dan bermakna. Langka-langkah membaca yang tertera dalam metode PQ4R dibuat untuk mempermudah siswa mengingat dan memahami materi ajar. bila dibandingkan dengan metode pembelajaran langsung, yang mana siswa hanya bersikap pasif menerima materi ajar dari guru, dan tidak dituntut untuk mencari dan menggali sendiri terkait materi ajar dengan membaca. 


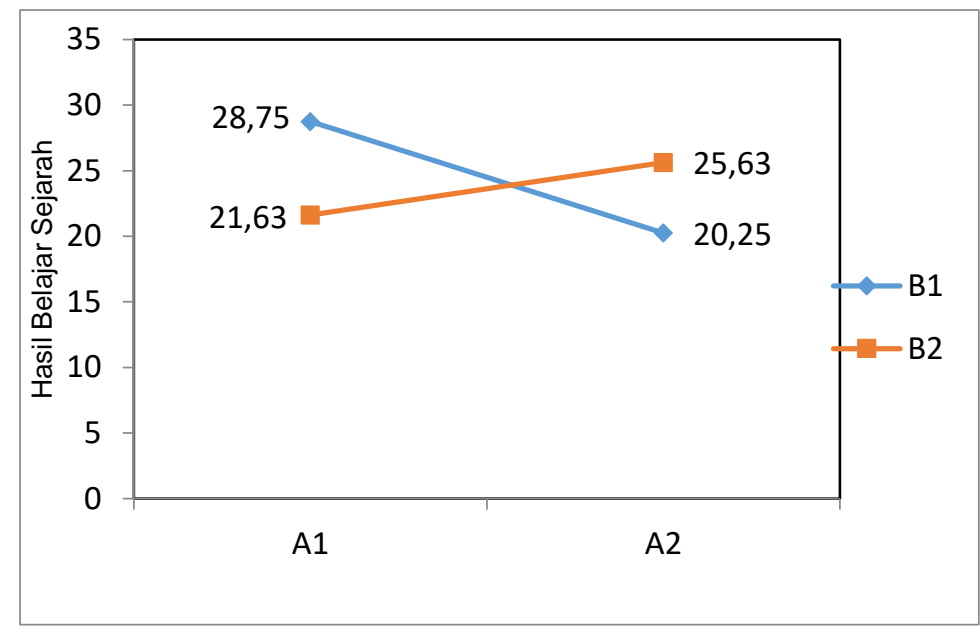

\section{Gambar. 1 Grafik Interaksi antara Metode Pembelajaran, Minat Baca dan Hasil Belajar Sejarah}

Hipotesis kedua menyatakan bahwa terdapat pengaruh interaksi antara metode pembelajaran dan minat baca siswa terhadap hasil belajar sejarah siswa. Yang dinyatakan dengan $\mathrm{H}_{0}$ : INT. $\mathrm{A} \times \mathrm{B}=0$ dan $\mathrm{H}_{1}$ : INT. $\mathrm{A} \times \mathrm{B} \neq 0$. Berdasarkan hasil perhitungan ANAVA terlihat bahwa $F_{\text {hitung }}$ untuk faktor interaksi yaitu sebesar 44,473 sedangkan $F_{\text {tabel }}$ pada taraf nyata signifikansi $\alpha=0,05$ adalah 4,20 . Karena $F_{\text {hitung }}>$ $\mathrm{F}_{\text {tabel }}$ maka $\mathrm{H}_{0}$ ditolak dan $\mathrm{H}_{1}$ diterima. Dengan demikian dapat disimpulkan bahwa dalam penelitian ini terdapat pengaruh interaksi antara metode pembelajaran dan minat baca siswa terhadap hasil belajar sejarah siswa.

Hal ini memungkinkan karena metode pembelajaran adalah merupakan komponen penting untuk mencapai tujuan pembelajaran. Metode pembelajaran mencakup berbagai aspek yang perlu diperhatikan dalam proses pembelajaran. Sehingga metode pembelajaran yang tepat akan menciptakan proses pembelajaran yang memiliki kebermaknaan tinggi sehingga mampu meningkatkan hasil belajar siswa. Sedangkan minat baca menuntun siswa untuk aktif dalam menambah penguasaan materi pembelajaran dengan cara membaca materi ajar secara mandiri. Dikarenakan terdapat interaksi antara Metode pembelajaran dan minat baca, maka perhitungan dilanjutkan dengan uji Tukey untuk melihat hasil perbandingan di antara kelompok perlakuan penelitian.

Hipotesis ketiga dengan menggunakan kriteria pengujian $\mathrm{H}_{0}: \mu \mathrm{A} 1 \mathrm{~B} 1 \leq \mu \mathrm{A} 2 \mathrm{~B} 1$ dan $\mathrm{H}_{1}$ : $\mu \mathrm{A} 1 \mathrm{~B} 1>\mu \mathrm{A} 2 \mathrm{~B} 1$ pada taraf signifikansi $\alpha=0,05$. Nilai rerata hasil belajar sejarah yang diberikan metode pembelajaran PQ4R pada siswa yang memiliki minat baca tinggi (A1B1) adalah 28,75. Sedangkan nilai rerata hasil belajar sejarah yang diberikan metode pembelajaran langsung pada siswa yang memiliki minat baca tinggi (A2B1) adalah 20,25. Hasil penghitungan uji Tuckey diperoleh nilai Qhitung $=9,07$ lebih besar dari Qtabel $=4,04$. Maka $\mathrm{H}_{0}$ ditolak dan $\mathrm{H}_{1}$ diterima dengan demikian dapat disimpulkan bahwa hasil belajar sejarah siswa yang memiliki minat baca tinggi dan diberikan Metode pembelajaran PQ4R, lebih tinggi daripada hasil belajar sejarah siswa yang memiliki minat baca tinggi dan diberikan metode pembelajaran langsung. 
Dengan menerapkan metode PQ4R terhadap siswa yang memiliki minat baca yang tinggi ini, maka tingkat keberhasilan penguasaan materi ajar yang lebih besar pula. Siswa yang memiliki minat baca yang tinggi lebih mudah melaksanakan langkah-langkah PQ4R, mereka juga memiliki tingkat konsentasi membaca yang tinggi, dan kerelaan untuk meluangkan waktu yang mereka miliki untuk membaca, dan yang paling penting adalah siswa yang memiliki minat baca yang tinggi dapat memanfaatkan langkahlangkah proses membaca terstruktur dan bermakna yang terdapat dalam metode PQ4R. Menurut Sarimana (2016:80), siswa yang telah menerapkan metode PQ4R lebih tertarik untuk membaca bahkan lebih mudah memahami materi pelajaran. Namun untuk para siswa yang memiliki minat baca yang tinggi ini jika hanya diterapkan metode pembelajaran langsung, menyebabkan proses menguasaan materi yang mereka lakukan dengan membaca akan lebih lambat, karena para siswa ini tidak merasakan manfaat dari proses membaca terstruktur dan bermakna yang ada dalam metode PQ4R.

Tabel 4. Rangkuman Nilai Rata-rata Hasil Belajar Sejarah Kelas Eksperimen (A1) dan Kelas Kontrol (A2)

\begin{tabular}{|c|l|l|l|l|}
\hline $\begin{array}{c}\text { Kelompok } \\
\text { data }\end{array}$ & A1B1 & A2B1 & A1B2 & A2B2 \\
\hline Rata-Rata & 28,75 & 20,25 & 21,625 & 25,625 \\
\hline
\end{tabular}

Hipotesis keempat dengan menggunakan kriteria kriteria pengujian $\mathrm{H}_{0}: \mu \mathrm{A} 1 \mathrm{~B} 2 \geq \mu \mathrm{A} 2 \mathrm{~B} 2$ dan $\mathrm{H}_{1}: \mu \mathrm{A} 1 \mathrm{~B} 2<\mu \mathrm{A} 2 \mathrm{~B} 2$ pada taraf signifikansi $\alpha$ $=0,05$. Nilai rerata hasil belajar sejarah yang diberikan Metode pem-belajaran PQ4R pada siswa yang memiliki minat baca rendah (A1B2) adalah 21,63. Sedangkan nilai rerata hasil belajar sejarah siswa yang diberikan metode pembelajaran langsung dan memiliki minat baca rendah (A2B2) adalah 25,63. Hasil perhitungan uji Tuckey diperoleh hasil nilai Qhitung $=4,27$ lebih besar dari Qtabel=4,04. Maka $\mathrm{H}_{0}$ ditolak dan $\mathrm{H}_{1}$ diterima dengan demikian dapat disimpulkan bahwa hasil belajar sejarah siswa yang memiliki minat baca rendah dan diberikan metode pembelajaran PQ4R lebih rendah dari hasil belajar sejarah siswa diberikan model pembelajaran langsung pada siswa yang memiliki minat baca rendah.

\section{Tabel .5 Rangkuman Hasil uji Tuckey}

\begin{tabular}{|c|c|}
\hline Kelompok data & Angka Tuckey \\
\hline A1B1-A2B1 & 9,07 \\
\hline A1B2-A2B2 & 4,27 \\
\hline
\end{tabular}

Siswa yang memiliki minat baca yang rendah, sangat tergantung pada pembelajaran yang diberikan oleh guru, mereka tidak memiliki inisiatif untuk membaca saat di perintah oleh guru, dan kurang memiliki semangat dan konsentrasi yang tinggi dalam membaca, dan saat diterapkan metode PQ4R yang terjadi adalah para siswa yang memiliki minat baca yang rendah ini, tidak berniat dan serius untuk mengikuti setiap langkahlangkah membaca yang terdapat dalam metode PQ4R, dan berdampak pada proses penguasaan materi ajar yang rendah. Metode pembelajaran langsung ternyata dapat memberikan keuntungan kepada siswa yang memiliki minat baca yang rendah, karena hanya tinggal duduk dan menerima materi ajar yang diberikan oleh guru dan tidak dituntut untuk memiliki minat baca yang tinggi.

Guru terus memotivasi siswa untuk memiliki minat baca yang tinggi, karena dengan membaca dapat membantu siswa dalam 
memahami dan menguasai materi ajar secara lebih baik. Bagi guru sejarah, dalam mengajar disarankan untuk mengekslorasi metode pembelajaran yang efektif untuk membantu siswa dalam mencapai hasil belajar yang baik. Dan tidak lupa pula untuk mengidentifikasi berbagai karakteristik yang terdapat dalam diri siswa, dikarenakan beberapa metode pembelajaran akan memiliki tingkat kesuksesan yang baik saat disandingkan dengan karakteristik siswa tertentu. Sebagai contoh, metode PQ4R akan sangat baik diterapkan pada siswa yang memiliki minat baca yang tinggi.

Sekolah dapat menyediakan berbagai sumber-sumber buku pelajaran sejarah yang baik dan memiliki substansi materi yang lengkap. Banyak buku-buku pelajaran sejarah yang memiliki substansi materi yang buruk, dan seringkali hanya berbentuk ringkasan. Dan sangat tidak cocok digunakan sebagai sumber belajar, terutama bagi guru yang ingin menerapkan metode PQ4R. Untuk menerapkan metode PQ4R secara lebih baik lagi, guru mata pelajaran sejarah hendaknya juga mempertimbangkan posisi jam pelajaran sejarah disekolah. Siswa yang belajar sejarah di pagi hari atau menjelang siang, masih memiliki konsentrasi yang baik jika diperintahkan untuk membaca oleh guru, dibandingkan siswa yang belajar sejarah pada jam pelajaran terakhir atau menjelang pulang sekolah.

\section{KESIMPULAN}

Hasil penelitian ini menunjukkan bahwa: (1) hasil belajar sejarah siswa yang diberikan metode pembelajaran PQ4R lebih tinggi dari pada hasil belajar sejarah siswa yang diberikan metode pembelajaran langsung. (2) terdapat pengaruh interaksi antara metode pembelajaran dan minat baca siswa terhadap hasil belajar sejarah. (3) hasil belajar sejarah siswa yang memiliki minat baca tinggi dan diberikan metode pembelajaran PQ4R, lebih tinggi dari pada hasil belajar sejarah siswa yang diberikan metode pembelajaran langsung. (4) hasil belajar sejarah siswa yang memiliki minat baca yang rendah dan diberika metode pembelajaran $\mathrm{PQ} 4 \mathrm{R}$ lebih rendah dari pada hasil pembelajaran sejarah siswa yang di-berikan metode pembelajaran langsung.

\section{DAFTAR PUSTAKA}

Anderson, Lorin W. dan David R. Kartwohl. Kerangka landasan untuk pembelajaran, pengajaran dan asesmen, Jakarta: Pustaka Pelajar, 2015.

Basri, Hasan, Paradigma Baru Sistem Pembelajaran, Bandung: Pustaka Setia,2015.

Chipman, Susan F, Judith W.Segal dan Rebert Glaser, Thinking and Learning Skill, Vol 2: Research and open question, New York: Routledge, 2009.

Daryanto, Rahmawati. Teori Belajar dan Proses Pembelajaran yang Mendidik, Yogyakarta: Gava Media, 2015.

Gredler, Margaret E, Learning and Instruction: Teori dan Aplikasi, terjemahan Tri Wibowo, Jakarta: Remaja kencana,2011.

Hamid Hasan, Pendidikan Sejarah untuk memperkuat Pendidikan Karakter, Paramita Vol. 22 No. 1 - Januari 2012

Jihad, Asep dan Abdul Haris, Evaluasi Pembelajaran, Yogyakarta: Multi Presindo, 2010.

Kirby, John R, Angela Ball dan B. Kelly Geier, The Development of Reading Interest and Its relation to Reading Ability, Journal of Research in reading, Volume 34, Issue 3, 2011.

Kochhar, S. K. Pembelajaran Sejarah: Teaching of History, Terj. Purwanta dan Yovita Hardiwati, Jakarta: PT Grasindo, 2008. 
Makmun, Abin S. Psikologi Kependidikan: Perangkat sistem Pengajaran Modul, Bandung: Remaja Rosdakarya,2009.

Ortlieb, Evans. Beyond Just Book: Sparking's Children Interest in Reading, International Journal of Education 2010, Vol. 2, No. 2.

Palani, K.K. Promoting Reading habits And Creating Literate Society, Journal of Arts, Science \& Commence. Vol.-III, Issue 2(1), April 2012.

Renninger, K. Ann dan Suzanne E. Hidi, The Power of Interest for motivation and Engagement, New York: Routledge,2016.

Sadirman, Interaksi dan Motivasi Belajar Mengajar, Jakarta: Grafindo, 2007.

Rathus, Spencer A, Psychology: Concepts and Connections, Belmont: Wadsworth,2010.

Ruqiah Bibi dan Manzoor H.Arif, Effect of PQ4R study strategy in scholastic achievement of Secondary School Student in Punjab (Pakistan), Language in India. Volume 11 : 12 December 2011.

Sarimanah, Eri. Efectivenes of PQ4R Metacognitive stategy based reading learning models in junior high school. International Journal of Language Education and Culture Review, Vol. 2 (1) 2016.
Slameto. Belajar dan faktor yang mempengaruhinya, Jakarta: Rineka Cipta, 2010.

Slavin, Robert E. Psikologi pendidikan: Teori dan Praktik, Jakarta: PT.Indeks, 2008.

Suprijono, Agus, Model-model Pembelajaran Emansipatoris, Yogyakarta: Pustaka Pelajar, 2016.

Suyono dan Hariyanto, Implementasi Belajar dan Pembelajaran, Bandung: Rosdakarya, 2015.

Susanto, Heri. Seputar Pembelajaran Sejarah: Isu, Gagasan, dan Strategi Pembelajaran, Yogyakarta: Aswaja, 2014.

Semiawan, Corry R. Landasan Pembelajaran dalam Perkembangan manusia, Jakarta: Pusat Pengembangan kemampuan Manusia, 2007.

Suprijono, Agus. Model-model Pembelajaran Emansipatoris, Yogyakarta: Pustaka Pelajar, 2016.

Trianto, Mendesain model pem-belajaran inovatif, progresif, dan kontekstual: konsep, landasan dan implementasinya pada kurikulum 2013 (kurikulum tematik integratif/ TKI), Jakarta: Prenadamedia Group, 2014. 